\title{
GÜL POSASI KÜLÜNÜN SERAMIKK YÜZEYLERDE KULLANIMI
}

\author{
Use Of Rose Pulp Ash On Ceramic Surfaces
}

Serap ÜNAL ${ }^{1}$, Elif AKGEYIK ${ }^{2}$

\section{ÖZET}

İnsanlığın ateşi keşfiyle başladığı düşünülen seramiğin serüveninde, ilk başlarda salt işlevselliğin önde olduğu sırsız çanak çömlekler üretildi. Sonraları ise, seramik formlara hem işlevsel hem de estetik görüntü veren seramik sırları keşfedildi. Ateşin yanması ile oluşan küllerin seramik yüzeylere yapışması sonucu oluşan farklı efektler ve parlaklık günümüzde kullanılan sır malzemesinin temellerini oluşturduğu bilinmektedir. Külün seramik yüzeylerde kullanımı M.Ö 1500 'lere tarihlenmektedir. Kül sırları kullanılarak yapılan en eski seramik örnekler, kuzey Çin de Shangxi bölgesinde Yuangu olarak bilinen seramik formlardır. Kül sırlarının, Çinli çömlekçi ustalarının çömleklerini pişirirken odun küllerinin uçuşarak çömleklerin yüzeylerine düşmesi sonucu rastlantısal olarak bulunmuştur. Geçen süreç içerisinde organik maddelerin (ağaç, bitki, meyve, sebze vb.) yakılması sonucu elde edilen külün içeriğinde bulunan zengin alkali kaynaklar, bitkinin yetiştiği ortam iklim koşulları, bitkinin kullanıldığı kısmı kül sırının oluşmasında etkendir. Tüm bunların yanısıra külün elde ediliş şekli ( kalsinasyon), yüzeye daldırma, firçayla sürme (sulu, susuz kullanım) kısacası tüm bu farklılıklar sırın farklı efektler vermesine neden olan etmenlerdir. Kül sırları geçmişten günümüze ucuz olması kolay bulunmasından dolayı seramik yüzeylerde kullanılmış olmasının yanısıra, organik atık maddelerin değerlendirilmesi açısından oldukça önemlidir. Atık malzemelerin değerlendirilmesi hem çevre dengesi açısından hem de ülke ekonomisi açısından oldukça önemli bir artı girdi olarak düşünülmektedir. Günümüzde, endüstriyel gül tarımında ve üretiminde dünya çapında yeri olan Isparta ve yöresinde kırsal ve endüstriyel gül yağı üretimi ile üretim sonrası ortaya çıkan organik atık madde gül posasının geri kazanılması, bölge ve ülke ekonomisine artı bir değer katması açısından önemlidir. Seramik endüstrisindeki teknolojik gelişmelerle kullanım alanları büyük bir hızla artan seramik malzemeler, kullanılan doğal kaynakların hızla azalmasına çevresel dengenin de bozulmasına neden olmaktadır. Organik atık malzemelerin (gül posası) sır malzemesi olarak kullanımı sanatsal seramik çalışmaları için oldukça iyi sonuçlar vermektedir. Sanatsal çalışmalarla birlikte endüstriyel kapsamda pek çok malzemenin seramik sanatı/endüstrisinde sır bileşeni olarak kullanılabilirliğ araștırılmaktadır. Bu çalıșmada; Isparta Gülü (Rosa Damescena)'nün, gül yağı imalatı sonrası atık gül posasının, seramik yüzeylerde kül sırı

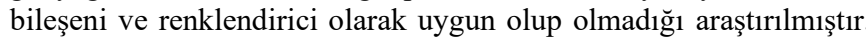
Gül posası külünün ergiticiler kullanılarak hazırlanan reçeteleri $1070^{\circ} \mathrm{C}^{\prime} \mathrm{de}$ pişirilerek, elde edilen olumlu sonuçlar neticesinde gerek sanatsal seramik çalışmalarında gerekse seramik endüstrisinde kullanılabileceği saptanmıştır. Geri dönüştürülen gül posası atıklarının ekolojiye ve ülke ekonomisine katkı sağlaması hedeflenmiştir.

Anahtar Kelimeler: Seramik Endüstrisi, Kül Sırları, Gül Posası.

\section{ABSTRACT}

In the ceramics adventure, which is believed to have started with the discovery of fire, the unglazed ceramics were produced in the beginning, while functionality was at the forefront. Later, ceramic glazes were discovered that gave ceramic forms both a functional and aesthetic appearance. It is known that the different effect and brightness created by the adhesion of the ashes formed by fire to the ceramic surfaces forms the basis of the glaze material used today. The use of ash on ceramic surfaces dates back to $1500 \mathrm{BC}$. The earliest examples of pottery made using ash glaze are forms of pottery known as Yuangu in Shangxi, northern China. Wood ash glaze was found by chance as a result of wood ashes flying off the pottery surfaces while Chinese pottery craftsmen baked their pottery. In the course of time, the rich alkaline sources contained in the ash obtained as a result of burning organic materials (trees, plants, fruits, vegetables, etc.), the ambient climatic conditions in which the plant is grown, and the part where the plant is used are factors in the formation of ash glaze. In addition to all these, the way the ash is obtained (calcination), dipping on the surface, brushing (wet, waterless use), in short, all these differences are the factors that cause the glaze to give different effects. Ash glazes are very important in terms of the evaluation of organic waste materials as well as their use on ceramic surfaces due to their cheapness from the past to the present. The use of waste materials is considered as a very important plus input in terms of both the environmental balance and the national economy. Rural and industrial rose oil production in Isparta and its region, which has a worldwide place in industrial rose agriculture and production today, and recovery of organic waste material rose pulp after production are gaining importance for the economy of the region and the country. Ceramic materials, whose usage areas have increased rapidly with the technological developments in the ceramic industry, cause the rapid decrease of the natural resources used and the deterioration of the environmental balance. The use of organic waste materials (rose pulp) as glaze material gives very good results for artistic ceramic works. Along with artistic works, the usability of many materials in the industrial scope as a glaze component in the ceramic art / industry is investigated. In this study; It was investigated whether Isparta Rose (Rosa Damescena), the waste rose pulp after rose oil production, is suitable as ash glaze component and colorant on ceramic surfaces. It has been determined that rose pulp ash can be used both in artistic ceramic works and in the ceramic industry as a result of the positive results obtained by firing the recipes prepared using smelters at $1070^{\circ} \mathrm{C}$. It is aimed that recycled rose pulp wastes will contribute to the ecology and economy of the country.

Keywords: Ceramic Industry, Ash Glazes, Rose Pulp.
1. ORCID: 0000-0003-2407-1789 2. ORCID: 0000-0003-4554-2164
1. Doç. Dr. Süleyman Demirel Üniversitesi, Güzel Sanatlar Fakültesi, Seramik ve Cam Bölümü, e-posta: serapunal@sdu.edu.tr

2. Master Student, Süleyman Demirel Üniversitesi, Güzel Sanatlar Enstitüsü, Sanat ve Tasarım Anasanat Dalı, eposta: elifakgyk123@gmail.com 


\section{EXTENDED ABSTRACT}

During the Shang Dynasty (1500 BC) in the Chinese Dynasty, the ashes burned during cooking coincidentally adhered to ceramic forms, ensuring that the ash glaze has been used on ceramic surfaces from past to present. Ash glazes have never lost their significance for the evaluation of organic / inorganic waste materials. The usability of many materials other than ash glazes and glaze raw materials as a glaze component in the ceramic art / industry continues to be explored.

The rapidly developing ceramic industry continues to be used in many different fields, and the glaze components (Kaolin, Feldspar, Quartz, etc.) used in industrial production are largely depleted by the natural mineral resources of inorganic minerals, causing the ecological balance to deteriorate gradually.

Ash glazes, which can be obtained from any organic or inorganic material that can turn into ash, positively affect the ecology and economy, especially when waste materials can be used. Gradually decreasing raw material resources used in the ceramic industry reveals more sustainable resources by recycling organic and inorganic wastes. The usability of many materials other than ash glazes and glaze raw materials as a glaze component in the ceramic art / industry continues to be explored.

The rapidly developing ceramic industry continues to be used in many different fields, and the glaze components (Kaolin, Feldspar, Quartz, etc.) used in industrial production are largely depleted by the natural mineral resources of inorganic minerals, causing the ecological balance to deteriorate gradually.

Ash glazes, which can be obtained from any organic or inorganic material that can turn into ash, positively affect the ecology and economy, especially when waste materials can be used. Gradually decreasing raw material resources used in the ceramic industry reveals more sustainable resources by recycling organic and inorganic wastes. Studies on recycling mostly industrial inorganic wastes ensure the use of less processed energy and available raw materials.

Isparta Rose (Rosa Damascena), which is produced intensely in the western Mediterranean region, in the region of Isparta and around the lakes, meets $65 \%$ of the world's total rose oil needs. The recovery of organic waste rose pulp emerging after production with village type and industrial rose oil production is important in terms of adding an added value to the economy of the region and the country.

Rose cultivation of the whole world, who are among the countries where a significant amount of Turkey, Bulgaria, Morocco, the Commonwealth of Independent States, Mexico, the total rose is about flower production averaged 40,000 tons in Iran are used for the production of rose oil in a large majority of this production. The waste pulp that emerges after production is emptied from the boilers and kept in the storage pits opened in the fields in order to decrease the water in the rose pulp by evaporation or seepage. Although different recycling options are researched for rose pulp, a significant amount remains as waste and cannot be evaluated.

Plants generally consist of hydrogen and carbon compounds. As a result of combustion, six main ceramic oxides (alumina, silica, calcium, sodium, potassium and magnesium) become ashes. Considering the chemical analysis of this ash, it is seen that they contain 10-15\% Al2O3, 30-70\% $\mathrm{SiO} 2$, up to $15 \% \mathrm{Na} 2 \mathrm{O}$ and $\mathrm{K} 2 \mathrm{O}, 30 \% \mathrm{CaO}$ and a small amount of Fe2O3 (Gündeşlioğlu Demir \& Tizgöl, 2016, p. 14 ).

This scope of work; The use of Isparta Rose (Rosa Damescena) as the ash glaze component and colorant on ceramic surfaces was investigated after the production of rose oil.

Rose flowers collected in 2017 in the town of Güneykent in Isparta province, used in the study, village type retort boilers made of copper, 20 liters of water and $20 \mathrm{~kg}$ of rose flowers were added by İsmail Baltac1 and distilled in copper boilers heated by wood fire for 2 hours. It was. The resultant rose pulp waste was incinerated into ash, and element analysis was made from ash, calcined at $1050{ }^{\circ} \mathrm{C}$. In the results obtained, the amount of elements that can form a glaze component has been determined. In order to see the effects of glaze, four different types of ceramic plates (Stoneware, Red Mud, Chamotte Mud, White Mud) plates, which are frequently used in the ceramic industry and artistic works, were prepared with the help of plaster molds, the plates were dried and biscuit firing was carried out. It was determined that the rose pulp ash was prepared using melters and cooked at $1070^{\circ} \mathrm{C}$, as a result of the positive results obtained, it can be used both in artistic ceramic works and in the ceramic industry. Recycled rose pulp wastes are aimed to contribute to ecology and the country's economy. 


\section{GíRis}

Çin Hanedanlığı Shang döneminde (M.Ö 1500), üretildiği bilinen seramiklerin sıra kavuşmasında pişirme sırasında yakılan odun küllerinin tesadüfen seramik formlara yapışması sonucu oluşan etkilerin, günümüz sır bileşenlerinin temellerini oluşturduğu bilinmektedir (Rogers, 2003, s. 11).

Günümüzde kullanılan endüstriyel sır hammaddeleri, büyük oranda inorganik minerallerin doğal maden kaynaklarıdır. Bunun yanı sıra organik sır hammaddelerinin daha çok sanatsal seramik uygulamalarında kullanıldığı görülmektedir. Seramik endüstrisindeki teknolojik gelişmelerle kullanım alanları büyük bir hızla artan seramik malzemeler, kullanılan doğal kaynakların hızla azalmasına ve ekolojik dengenin giderek bozulmasına neden olmaktadır.

Tesadüflerin şekillendirdiği seramik sırlarındaki bu rastlantısal oluşumların odun külleri ile ortaya çıkmış olması, kül sırlarını seramik uygulamaların içerisinde daha etkili kullanma çabalarına neden olmuştur. Küller farklı ergiticilerle hazırlanan reçeteler ile kullanıldıklarında farklı matlık/parlaklık, doku ve renk efektleri verebilmektedir.

Yanıp kül haline gelebilen organik ya da inorganik her malzemeden elde edilebilen kül sırları, özellikle atık malzemelerin kullanılabildiği durumlarda ekolojiyi ve ekonomiyi olumlu şekilde etkilemektedir. Seramik endüstrisinde kullanılan hammadde kaynaklarının giderek azalması organik ve inorganik atıkların geri dönüşümü ile daha sürdürülebilir kaynaklar ortaya çıkarmaktadır. Daha çok endüstriyel inorganik atıkların geri kazanılması ile ilgili çalışmalar, işlenmiş halde bulunan, az enerji ve mevcut hammadde kaynaklarının kullanımını sağlamaktadır.

Çalışmamıza yön veren kül sırlarının, seramik sır bileşenlerinde hammadde kaynağı olarak daha sürdürülebilir olduğu ve ekolojik katkısı düşünülmüştür. Isparta'da tarımı yapılan gül yağı (Rosa Damascane) imalatı sonrasında oluşan gül posasının, kül sırı reçeteleri ile seramik yüzeylerde kullanılması sonucu elde edilen olumlu sonuçlar ile sanatsal seramik çalışmalarında ve endüstriyel seramik üretiminde kullanılabileceği tespit edilmiştir.

\section{GÜL POSASI}

Batı Akdeniz bölgesi, Göller yöresi Isparta ili ve çevresinde yoğun bir şekilde üretilen Isparta Gülü, yılın 60 günü hasat edilerek toplanan gül çiçekleri, gül yağı elde edilmek üzere fabrikalara gönderilir ve burada yapılan damıtma prosesi sonucu elde edilen gül yağı dünya gül yağı ihtiyacının \%60 - 65'ini karşılamaktadır (2017 Yılı Gül Çiçeği Raporu, 2018).

Gül yetiştiriciliğinin önemli miktarda yapıldığı ülkeler arasında bulunan Türkiye, Bulgaristan, Fas, Bağımsız Devletler Topluluğu, Meksika, İran'ın 1990 yılı verilerine göre dünyada toplam gül çiçeği üretimi 40000 ton olup ülkelere göre dağılımı aşağıdaki tabloda verilmişstir (Avşar, Kurt, Tosun, \& Günay, 2005).

\begin{tabular}{ll}
\hline Ülke & Toplam Üretim (ton) \\
\hline Türkiye & 22.000 \\
\hline Bulgaristan & 10.400 \\
\hline Fas & 3.600 \\
\hline Meksika & 1.800 \\
\hline Bağımsiz Devletler Topluluğu & 1.800 \\
\hline Iran & 450 \\
\hline
\end{tabular}

Tablo 1. 1990 Yılı Verilerine Göre Dünya Toplam Gül Çiçeği Üretimi Verileri

Endüstriyel damıtma süreçleri köy tipi imbiklerin çalışma prensiplerine büyük ölçüde benzerlikler göstermekle birlikte, 3000 litrelik bakır veya paslanmaz çelik imbik kazanlar kullanılmaktadır. 400 - 500 kg gül çiçeği için 1500 - 2000 lt su kullanılarak 1/3 oranın da damıtma işlemi yapılmaktadır.

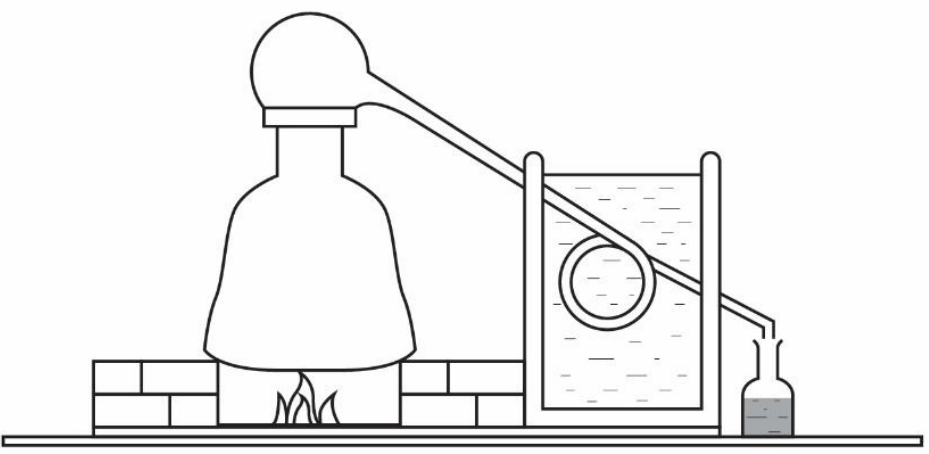




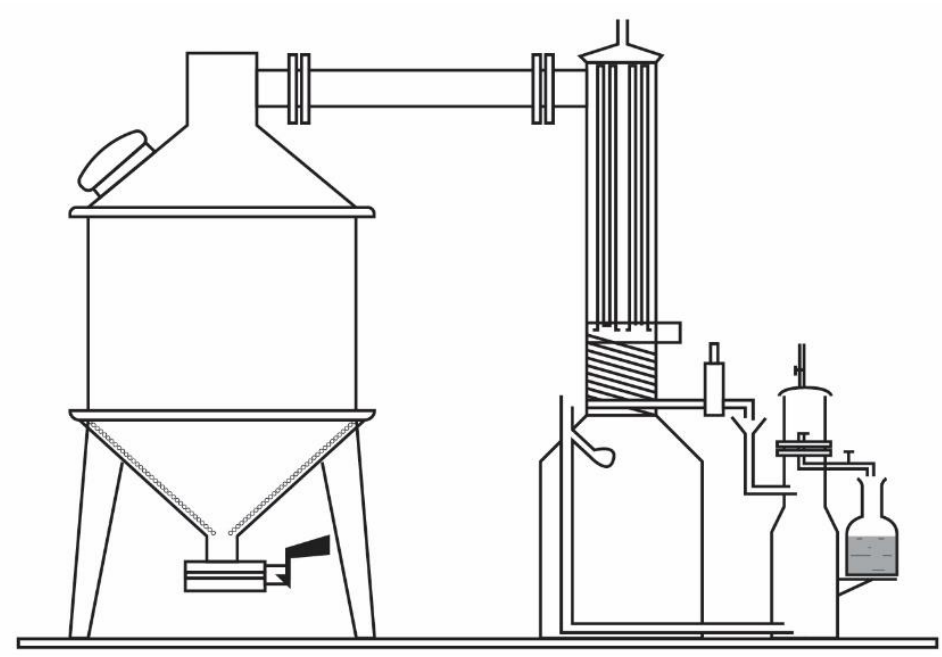

Şekil 2. Endüstriyel Tip Damıtma Kazanları (Akgeyik, 2020).

Damıtma sonrası posalar, kazanlardan boşaltılarak genellikle arazilerde açılan depolama çukurlarında gül posasındaki suyun buharlaşma ya da sızma yoluyla azalması için bekletilmektedir. Gül posasının depolandığı çukurlarda anaerobik ayrışma sonucu çevreyi rahatsız edici kokular oluşmaktadır (Tosun, Gönüllü, \& Arslankaya, 2002).

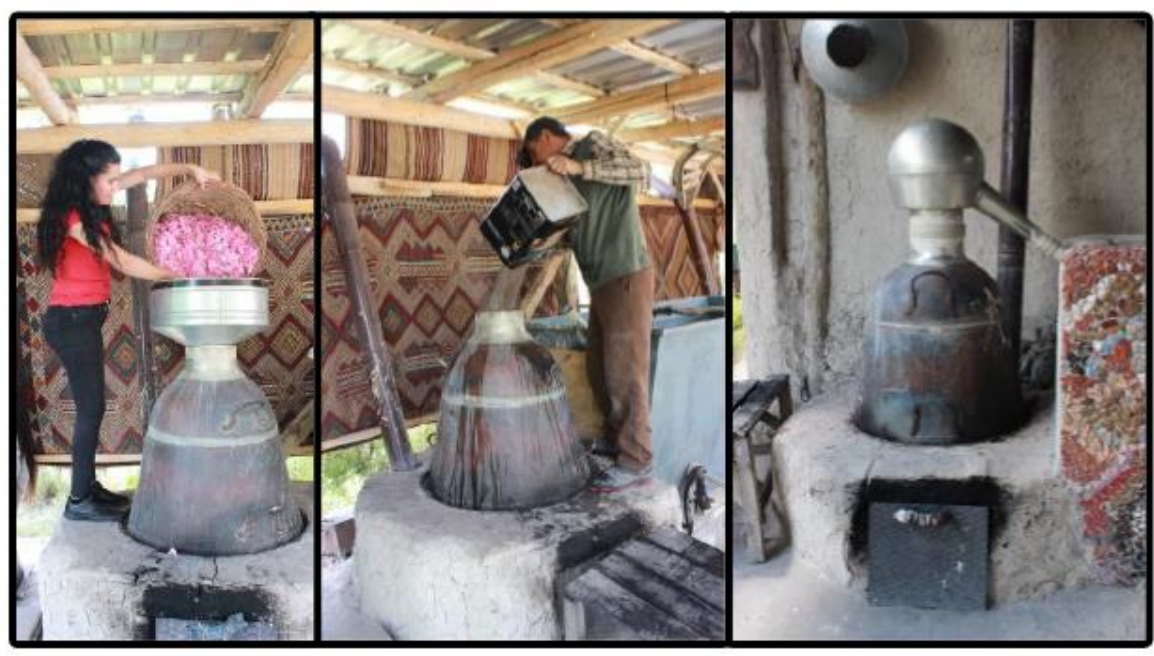

Şekil 3. Damıtma İşlemi - Gül Çiçeklerinin ve Suyun İmbiklere Konulması (Akgeyik, 2018).

Çalışma da kullanılan, Isparta ili Güneykent kasabasında 2017 yılında toplanan gül çiçekleri, bakırdan yapılmış köy tipi imbik kazanlarına, İsmail Baltacı tarafından 20 litre su ve $20 \mathrm{~kg}$ gül çiçeği ilave edilerek, 2 saat odun ateşi ile 1sıtılan bakır kazanlarda damıtma işlemi yapılmış ve gül yağı elde edilmiştir. 


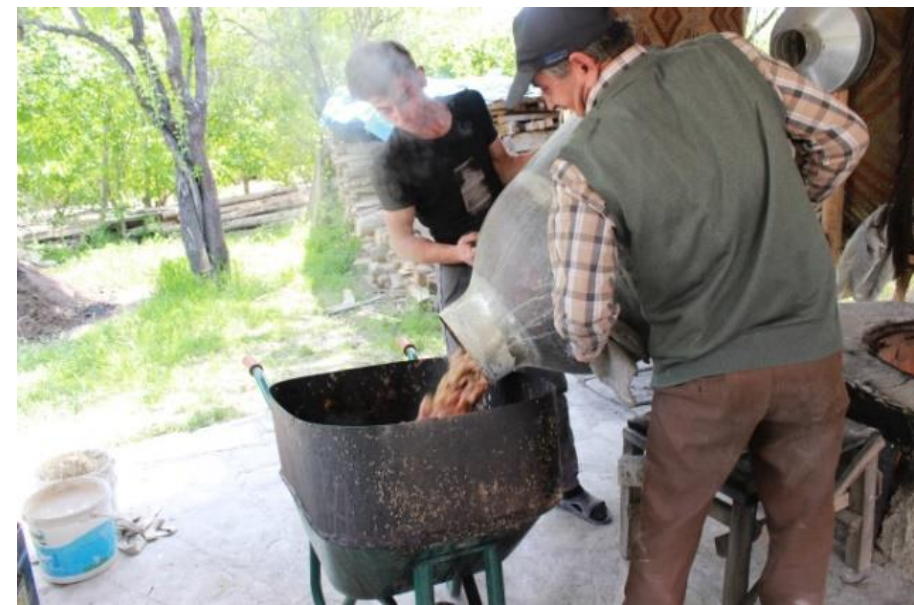

Şekil 4. Damıtma İşlemi Sonrası Gül Posasının Boşaltılması (Akgeyik, 2018).

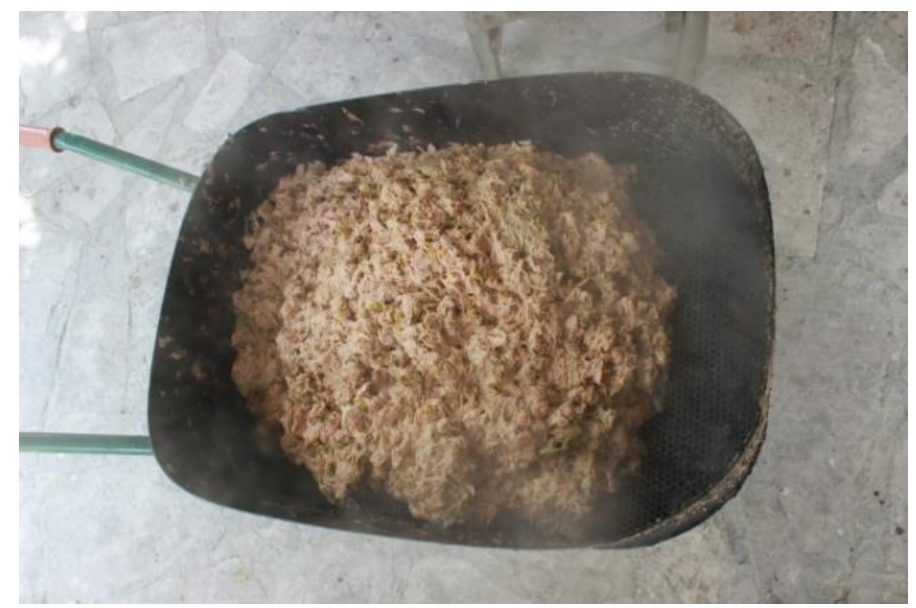

Şekil 5. Damıtma İşlemi Sonrası Sıcak Haldeki Gül Posası (Akgeyik, 2018).

Elde edilen gülyağı şişelere konulmuş ve depolanmak üzere serin bir yere kaldırılmıştır. Damıtma işlemi sonrası ortaya çıkan gül posası imbiklerden boşaltılıp, kurutulmak üzere boş arazi üzerine briket haline getirilmiştir. Kuruyan gül posası çalışmada kullanılmak üzere toplanmıştır.

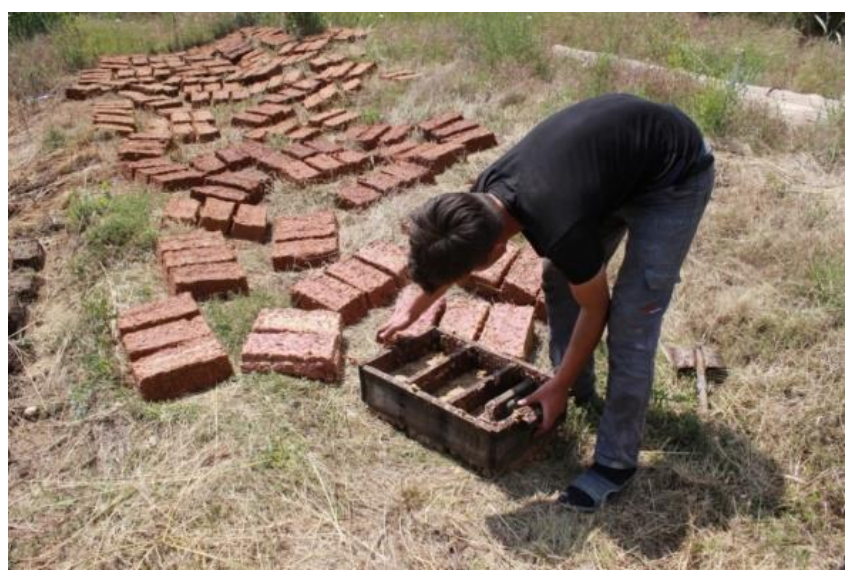

Şekil 6. Boşaltılan Gül Posalarının Briket Haline Getirilmesi (Akgeyik, 2018). 


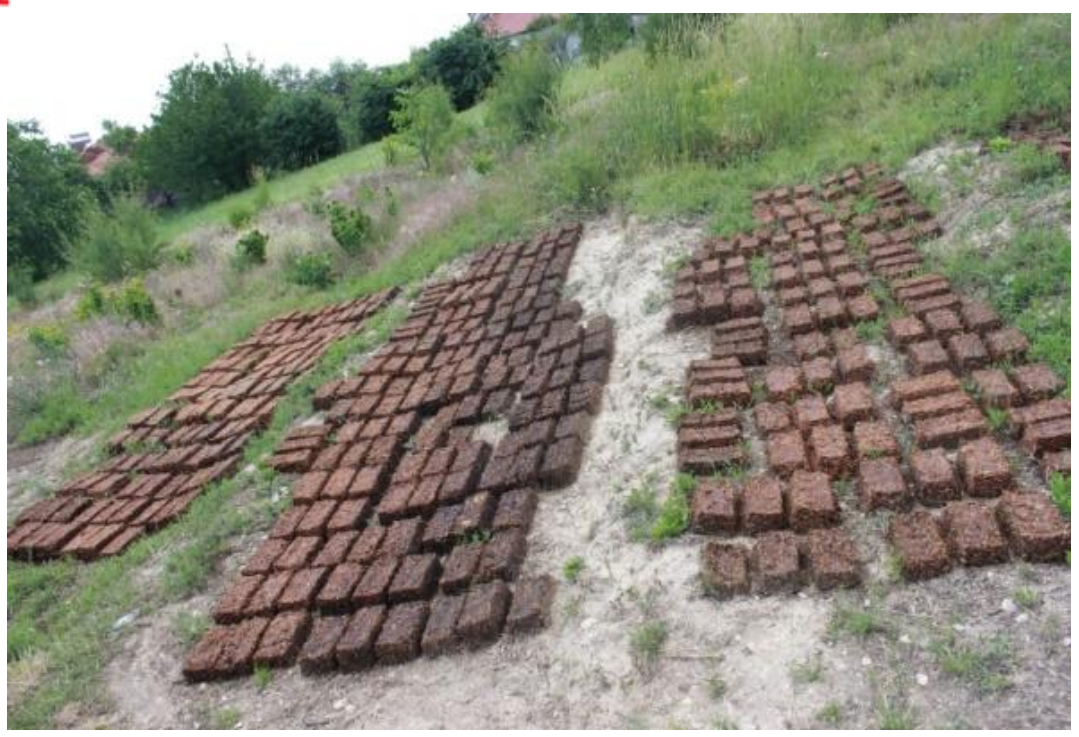

Şekil 7. Briket Haline Getirilen Gül Posalarının Boş Araziye Serilerek Kurutulması (Akgeyik, 2018).

Bitkiler genel olarak hidrojen ve karbon bileşiklerinden oluşmaktadır. Yanma sonucu altı ana seramik oksit (alümina, silis, kalsiyum, sodyum, potasyum ve magnezyum) kül yığını halini alır. Bu külün kimyasal analizine bakıldığında, \%10-15 Al2O3, \%30-70 SiO2, \%15'e kadar $\mathrm{Na} 2 \mathrm{O}$ ve $\mathrm{K} 2 \mathrm{O}, \% 30 \mathrm{CaO}$ ve az miktarda da $\mathrm{Fe} 2 \mathrm{O} 3$ genel olarak içerdikleri görülür (Gündeşlioğlu Demir \& Tizgöl, 2016, s. 14)

\begin{tabular}{lc}
\hline Parametre & $\begin{array}{c}100 \text { gr kuru küspede gr } \\
\text { olarak }\end{array}$ \\
\hline $100^{\circ} \mathrm{C}$ de rutubet & 91,446 \\
\hline Mutlak kuru küspe nispeti & 8,554 \\
\hline Ham kül & 7,805 \\
\hline Organik madde & 92,194 \\
\hline $\mathrm{SiO}$ & 2,2133 \\
\hline $\mathrm{Ca}$ & 1,2914 \\
\hline $\mathrm{Mg}$ & 0,7766 \\
\hline $\mathrm{K}$ & 1,0327 \\
\hline $\mathrm{Fe}$ & 0,0590 \\
\hline $\mathrm{P}_{2} \mathrm{O}_{5}$ & 0,05932 \\
\hline $\mathrm{P}$ & 0,02588 \\
\hline $\mathrm{N}$ & 3,02037 \\
\hline
\end{tabular}

Tablo 2. Gül Posası Analiz Sonuçları (Özcan, 1998, s. 119)

Yakılan bitkinin çeşidi değiştikçe içerisindeki minerallerde değişeceğinden her bitki seramik bünyede kendine özgü efektler vermektedir. Bu nedenle gül bitkisinin yakılan posası da kendine özgü mineral ve oksit deposuyla seramik bünye üzerinde olağan üstü sır etkisi bırakmaktadır. Gül posası külleri firın atmosferinde sıra dönüşebilmek için minimum $1070^{\circ} \mathrm{C}$ 'ye ihtiyaç duymaktadır (Ünal \& Akgeyik, 2019, s. 572)

\section{MATERYAL VE YÖNTEM}

\subsection{Deneme Plakalarının Hazırlanması}

Sır etkilerini görebilmek için deneme plakaları alçı kalıplar yardımıyla, seramik endüstrisinde ve sanatsal çalışmalarda sıklıkla kullanılan dört tip farklı seramik (Stoneware, Kırmızı Çamur, Şamotlu Çamur, Beyaz Çamur) bünyeler hazırlanmış, plakalar kurutularak bisküi pişirimi gerçekleştirilmiştir.

\subsection{Külün Hazırlanması}

Isparta ili Güneykent kasabasında 2017 gül sezonunda toplanan gül çiçeklerinin damıtılması sonucu elde kalan kurutulmuş gül posaları depolanarak bekletilmiştir. 


\subsubsection{Posanın Yakılması}

Kurutulan gül posalarının yakılma işlemi gül posasının içine başka maddelerin karışmaması için daha önceden bisküi pişirimi yapılmış geniş ve derin seramik potada yapılmıştır. Posa yanıcı bir madde ile ateşlenmiş, yakılma işlemi sonrası bütün parçaların yanması için uzun süre köz halinde bekletilmiştir.

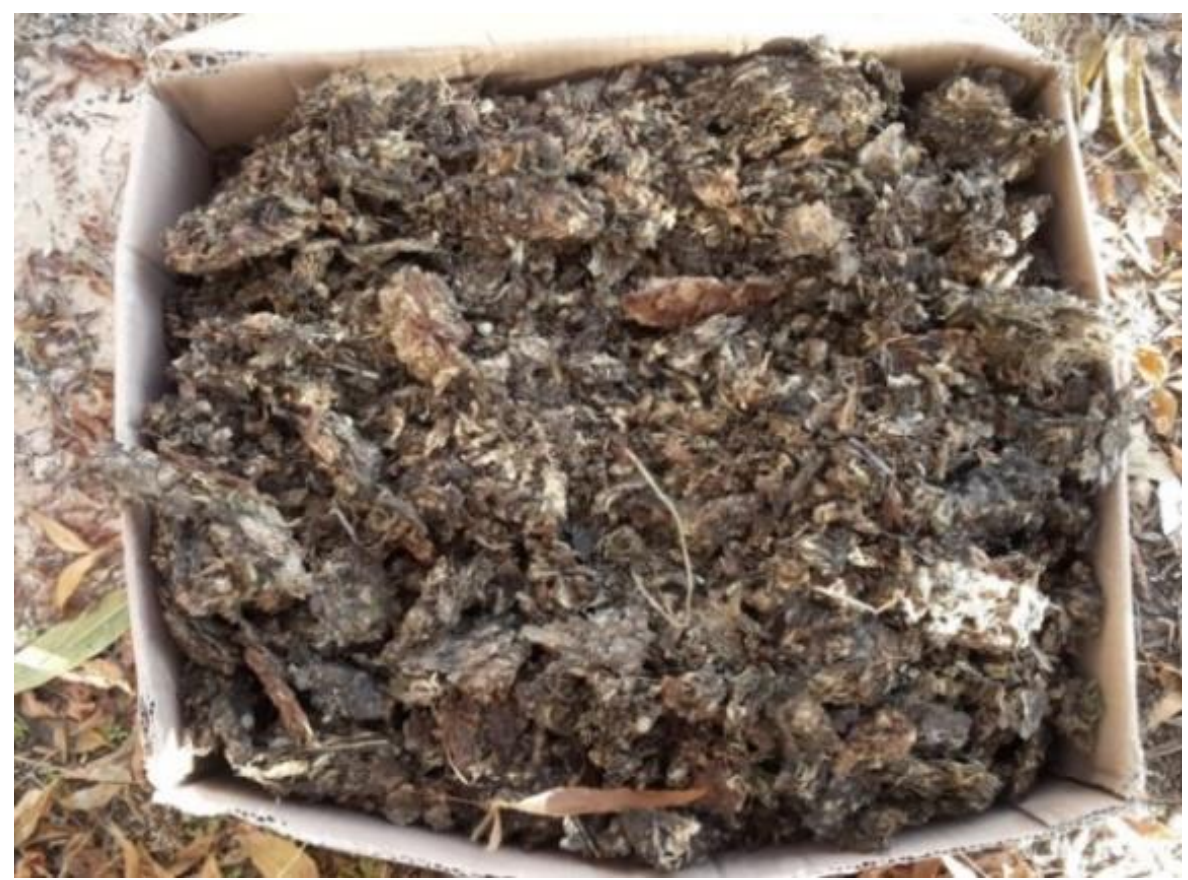

Şekil 8. Kurutulmuş Gül Posası (Akgeyik, 2018).

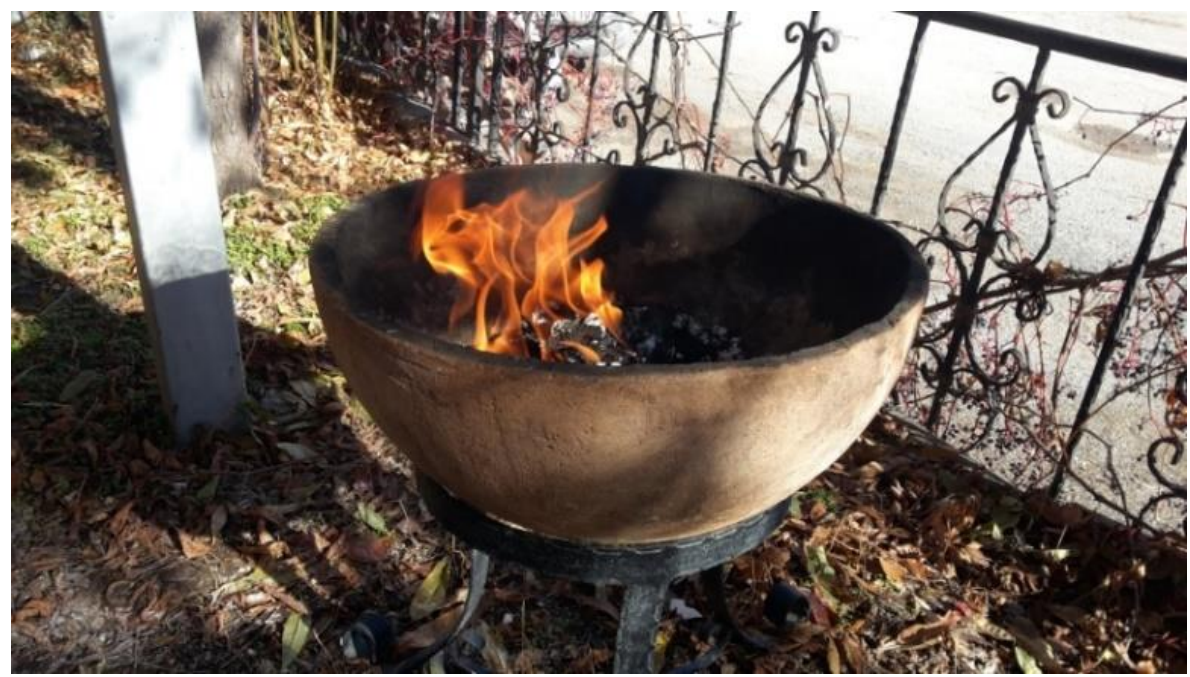

Şekil 9. Gül Posası Yakma İşlemi (Akgeyik, 2018). 


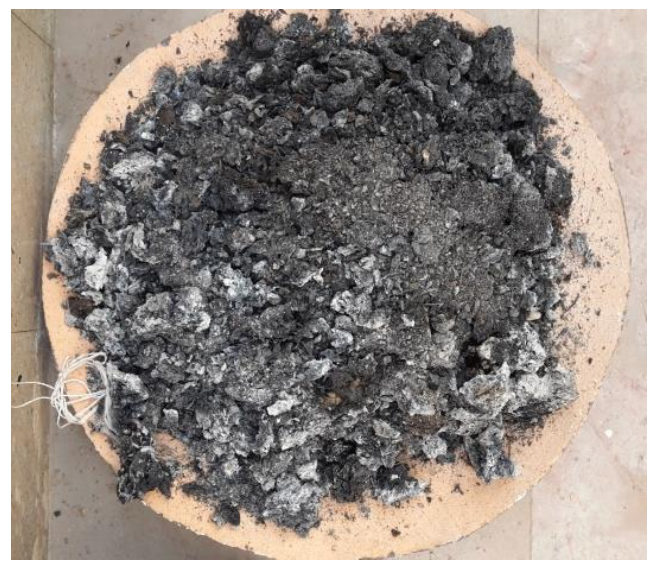

Şekil 10. Yakılmış Gül Posası (Akgeyik, 2018).

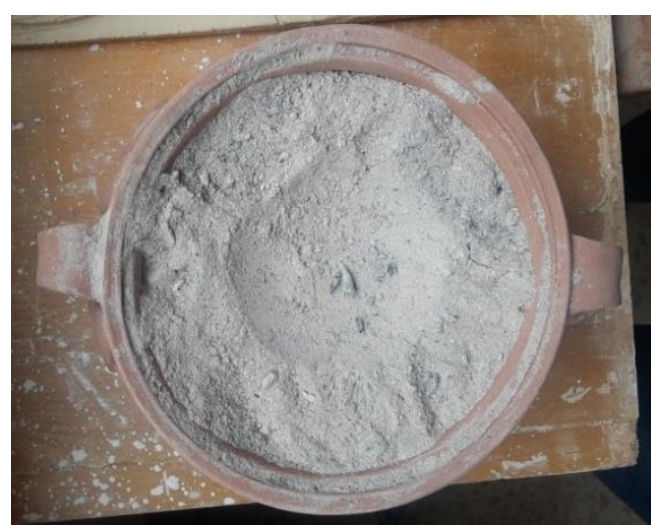

Şekil 11. Gül Posası Külü (Akgeyik, 2018).

Elde edilen külde yanmamış materyaller görüldügünden, yakılmış külün kalsinasyonu gerekli olmuştur. Tamamen yanan gül posası külü ince bir elekten geçirilerek başka geniş seramik kaba aktarılmış ve dinlendirilmiştir. Dinlenen küller küçük seramik kaplara doldurularak seramik fırınında $1050^{\circ} \mathrm{C}$ de kalsine edilmiştir.

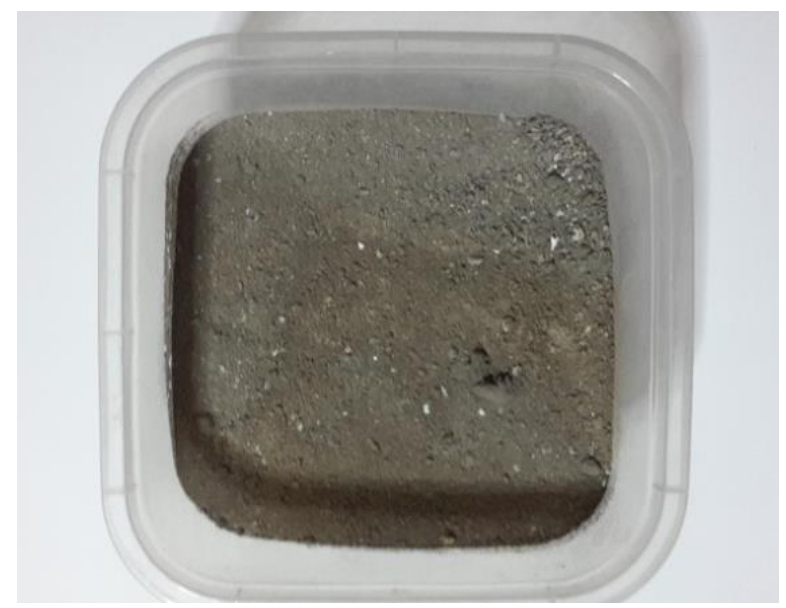

Şekil 12. Kalsine Edilmiş Gül Posası Külü (Akgeyik, 2018). 


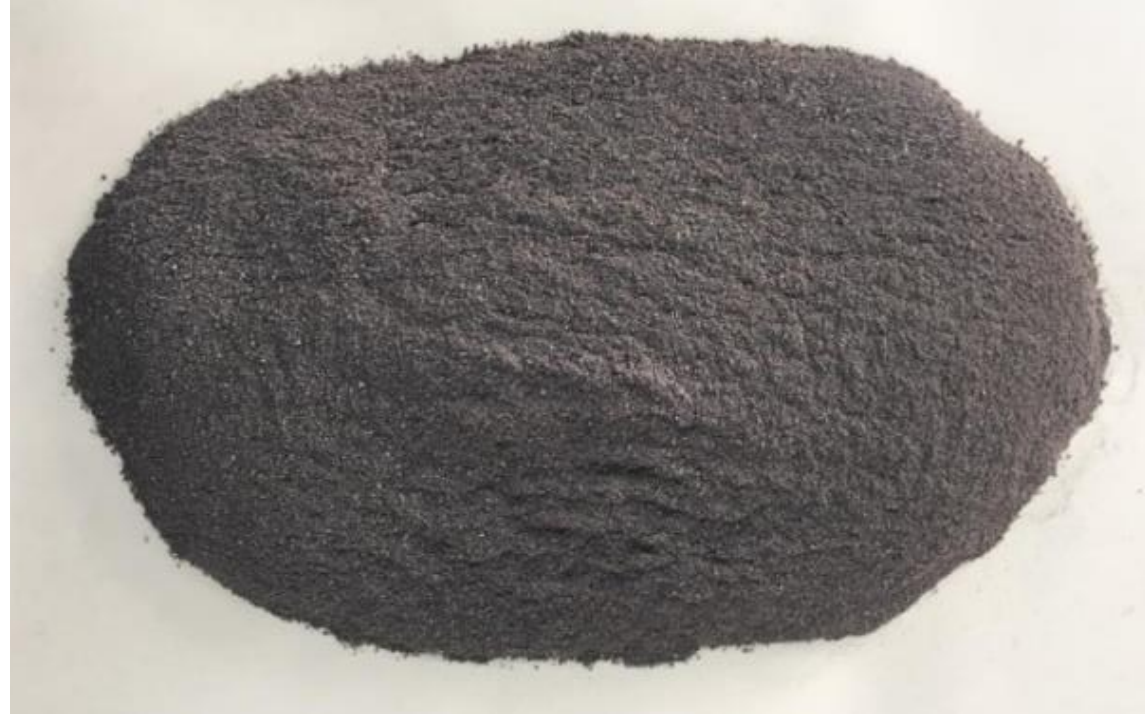

Şekil 13. Analiz İçin Ayrılan Kalsine Edilmiş Gül Posası Külü (Akgeyik, 2018).

Kalsine edilen külden element analizi yapılmak üzere bir miktar ayrılmış ve Süleyman Demirel Üniversitesi (SDÜ) Uygulamalı Temel Bilimler ve Teknolojileri Araştırma Birimi (YETEM) bünyesinde, Deneysel ve Gözlemsel Öğrenci Araştırma ve Uygulama Merkezi tarafindan, 06.06.2018 tarihinde yapılan analiz, Kral suyu ile (1HNO3 + 3 HCI) mikrodalga numune hazırlık firınında yaş yakma yapıldıktan sonra hacim 25 ml'ye tamamlanmış, EPA6010 metoduna uygun olarak Perkin-Elmer OPTIMA 5300 DV ICP OES cihazı ile çalışmamızda yakılarak kül haline getirilen gül posası kül içeriği analiz edilmiştir.

\begin{tabular}{lc}
\hline Numune adı & Element Derişimi (\%) \\
\hline $\mathrm{Al}_{2} \mathrm{O}_{3}$ & 1,95 \\
\hline $\mathrm{P}_{2} \mathrm{O}_{5}$ & 9,32 \\
\hline $\mathrm{Fe}_{2} \mathrm{O}_{3}$ & 1,47 \\
\hline $\mathrm{CaO}$ & 37,68 \\
\hline $\mathrm{K} \mathrm{O}$ & 13,47 \\
\hline $\mathrm{MgO}$ & 5,44 \\
\hline $\mathrm{MnO}$ & 0,26 \\
\hline $\mathrm{CuO}$ & 0,079 \\
\hline $\mathrm{SiO}_{2}$ & 4,01 \\
\hline $\mathrm{Na}_{2} \mathrm{O}$ & 0,77 \\
\hline
\end{tabular}

Tablo 3. Gül Posası Külü Analiz Sonuçları. SDÜ, YETEM, 06.06.2018 (Akgeyik, 2018).

\subsubsection{Kül Sırının Hazırlanması}

Külün yıkanması ya da yıkanmaması konusunda ki her iki süreç değerlendirildiğinde, tüm bitki küllerinin suda çözünen karbonatlar, sülfatlar ve klorlar gibi bileşikler içerdiği bilinmektedir (Andiç, 1994, s. 20). Kül sırının hazırlanması için seramik potalarda yakılarak $1050^{\circ} \mathrm{C}$ 'de kalsine edilen gül posası küllerinin içinde bulunan bileşiklere zarar vermemek ve yararsız hale gelmemesi amacıyla kül, yıkanma sürecine sokulmamıştır.

Küllerin büyük parçalardan arındırılması için kül mermerler arasında ezilmiş ve 9 mikronluk sır eleklerinden geçirilerek reçetelerde kullanılmak üzere ağzı kapalı kaplara konulmuştur. 

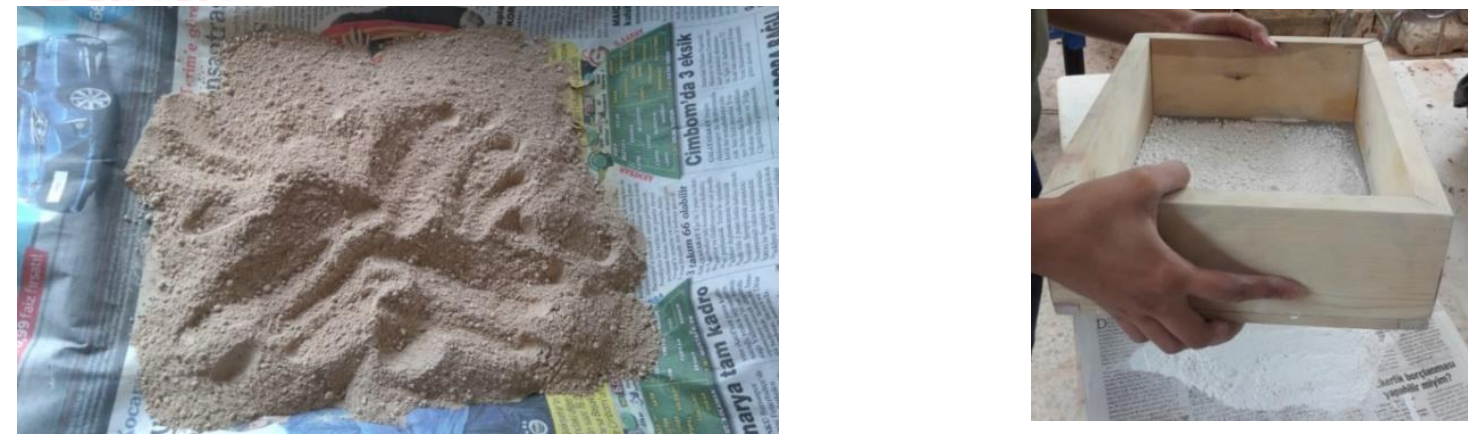

Şekil 14. 9 Mikronluk Eleklerden Geçirilen Gül Posası Külleri (Akgeyik, 2018).

\subsection{Reçetelerin Hazırlanması}

Hazırlanan gül posası külü yapılan analiz sonuçları değerlendirilerek, Renk veren oksitler kullanılmamış sadece ergitici olarak üleksit ve sülyen ile ikili ve üçlü harman olarak sır reçeteleri hazırlanmıștır. Hassas terazide gül posası külü, ergiticiler tek tek ölçülerek not tutulmuştur. Bunun için hassas terazide kağıdın ağırlığı da hesap edilerek ölçümler yapılmıştır.

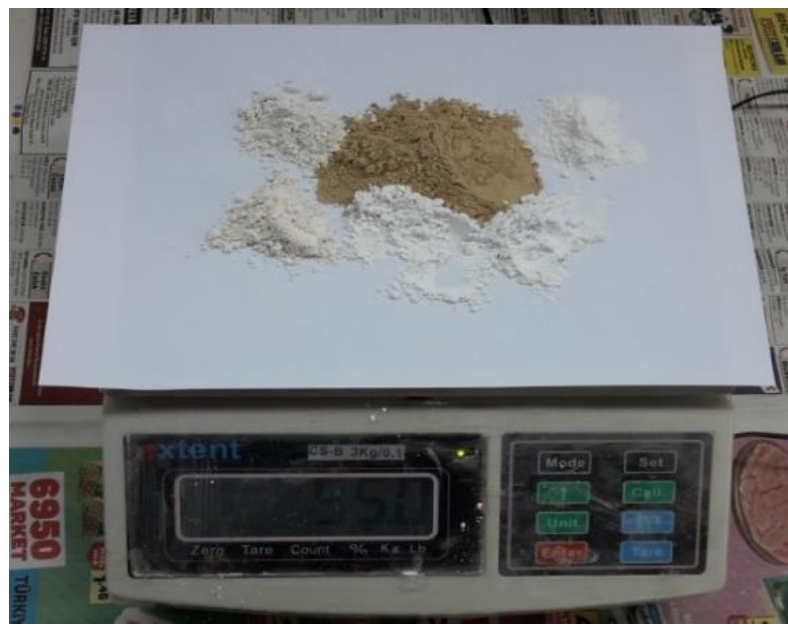

Şekil 15. Hassas Terazide Tartılan Gül Posası Külü ve Mineraller (Akgeyik, 2018).

Tartımı yapılan sırlar karıştırılarak üzerine etil alkol ilave edilerek iki mermer arasında öğütülmüştür. Deneme plakaları üzerine uygulanabilecek kıvamdaki kül sırı reçetesi vakit kaybetmeden kullanılmak üzere bir kaba alınmıştır.

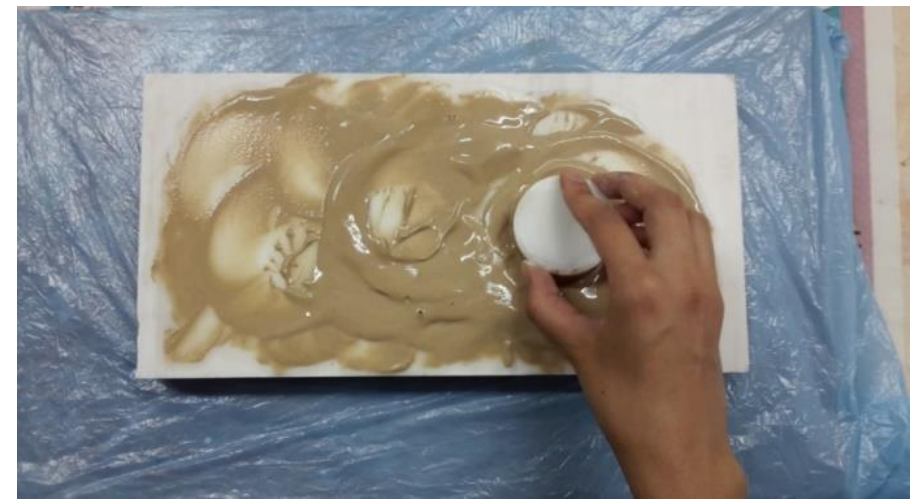

Şekil 16. Gül Posası Kül Sırının Öğütülmesi (Akgeyik, 2018).

Dört farklı seramik (Stoneware, Kırmızı Çamur, Şamotlu Çamur, Beyaz Çamur) bünye ile hazırlanan plakalar üzerine akıtma yöntemi ile uygulanan gül posası külü sırı uygulanan deney plakaları $1070{ }^{\circ} \mathrm{C}$ 'de elektrikli kamara tipi firında 8 saat pişirilmiştir. 


\subsubsection{Gül Posası Külü ve Sülyen İkili Harman Denemeleri}

Seramik yüzeyi kül sırı denemelerinde ikinci olarak gül posası külü ve üleksit kullanılarak yapılan ikili harmanların denemeleri yapılmıştır.

\begin{tabular}{|c|c|c|c|}
\hline Stoneware & Kirmızı Çamur & Şamotlu Çamur & Beyaz Çamur \\
\hline & & & \\
\hline
\end{tabular}

\%80 Gül posası külü ve \% 20 sülyen kullanılan ilk grupta gül posası külünün yüksek oranda kullanılması, sülyen miktarının yeterli gelmediği, stoneware çamurda mat kahverengi bir renk oluştuğu ve kırmızı çamur yüzeyinde sırın etkisiz kaldı̆̆ gözlemlenmiş, şamotlu çamur ve beyaz çamur üzerinde sırın erimediği ve olgunlaşmadığ görülmüştür.
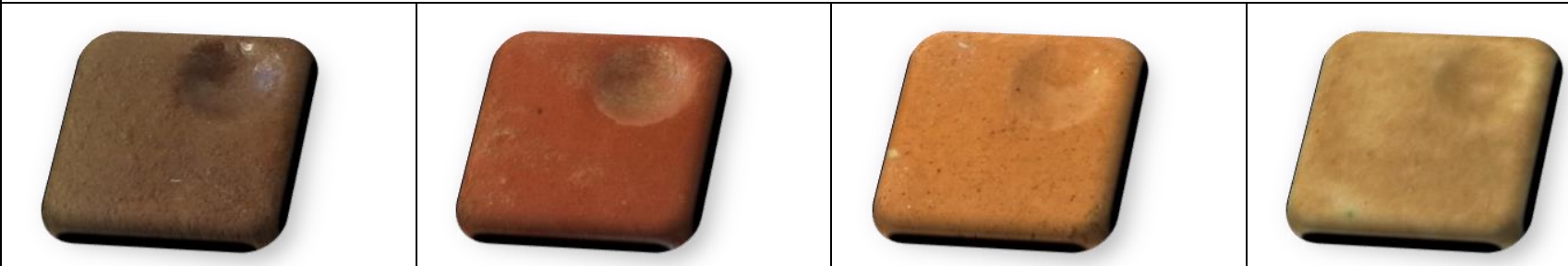

\%60 gül posası külü ve \% 40 sülyen kullanılan ikinci grupta stoneware çamurda gözlenen koyu koyu kahve renklenme devam etmiş ve bir miktar parlaklık oluşmuştur. Kırmızı çamurda parlaklık ve sır dokusu oluşumu gözlenmez iken şamotlu çamurda hafif parlaklık ve yüzey üzerinde benekler meydana gelmiştir. Beyaz çamurda ise kahverengi efektler oluşmuş az miktarda sır dokusu oluştuğu gözlemlenmiştir.

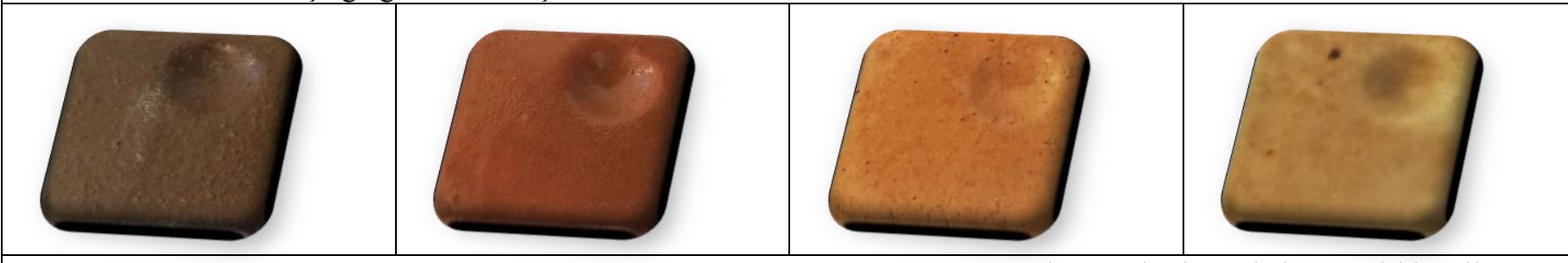

\%40 gül posası kül ve \%60 sülyen kullanılan üçüncü grupta stoneware çamurda pütürlü, koyu kahverengi bir miktar sır dokusu oluşurken, kırmızı çamurda yeterli miktarda parlaklık meydana geldiği görülmüştür. Şamotlu çamurda seyrek koyu benekler oluşurken beyaz çamurda açık kahverengi yüzey meydana gelmiştir.
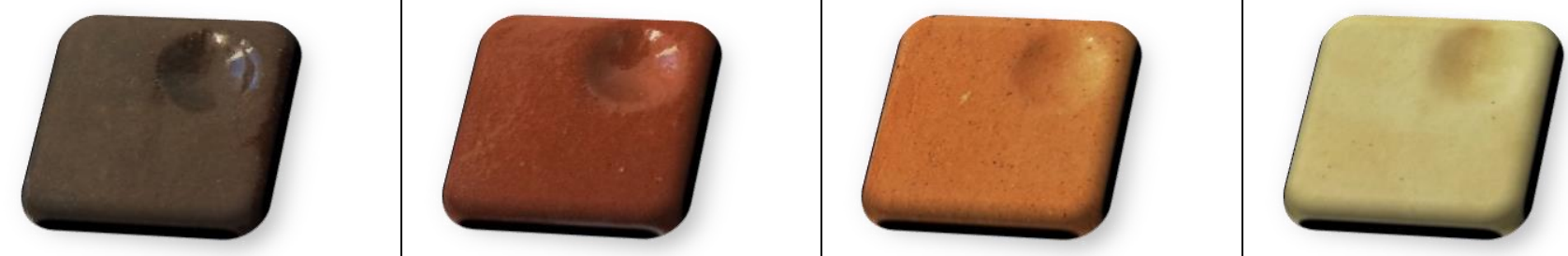

\%20 gül posası külü ve \%80 sülyen (eritici) kullanılan dördüncü grupta stoneware çamurda koyu kahverengi parlak sır yüzeyi belirgin şekilde olgunlaşmıştır. Kırmızı çamurda renk sonucu vermezken çamur yüzeyinde parlak sır dokusu oluşmuştur. Şamotlu ve beyaz çamurda parlak sır oluşumu meydana gelmezken, kül sırı oluşumu da gözlenmemiştir.

Şekil 17. Gül Posası Külü ve Sülyen İkili Harmanları

$1070^{\circ} \mathrm{C}$ 'de pişirilerek yapılan gül posası ve sülyen (eritici) kullanılarak hazırlanan harmanlarda kül miktarının \%60 seviyesinde kullanılması sonucu elde edilen sonuçların az miktarda sırlama dokusu oluşturabildiği ancak daha yüksek oranda sır yüzeyler elde etmek için kül miktarının \%50’nin altında kullanılması gerektiği tespit edilmiştir. 


\subsubsection{Gül Posası Külü ve Üleksit İkili Harmanları}

Seramik yüzeyi kül sırı denemelerinde ikinci olarak gül posası külü ve üleksit kullanılarak yapılan ikili harmanların denemeleri yapılmıştır.

\begin{tabular}{|c|c|c|c|}
\hline Stoneware & Kırmızı Çamur & Şamotlu Çamur & Beyaz Çamur \\
\hline & & & \\
& & &
\end{tabular}

\%80 gül posası külü ve \% 20 üleksit kullanılan ilk grupta gül posası külünün yüksek oranda kullanılması, üleksit miktarının yeterli gelmediği, stoneware çamurda ve kırmızı çamurda mat kahverengi bir renk oluştuğu gözlemlenmiş, şamotlu çamur üzerince sır oluşumu gözlenmezken, beyaz çamur üzerinde açık kahverengi dokular meydana gelmiştir.
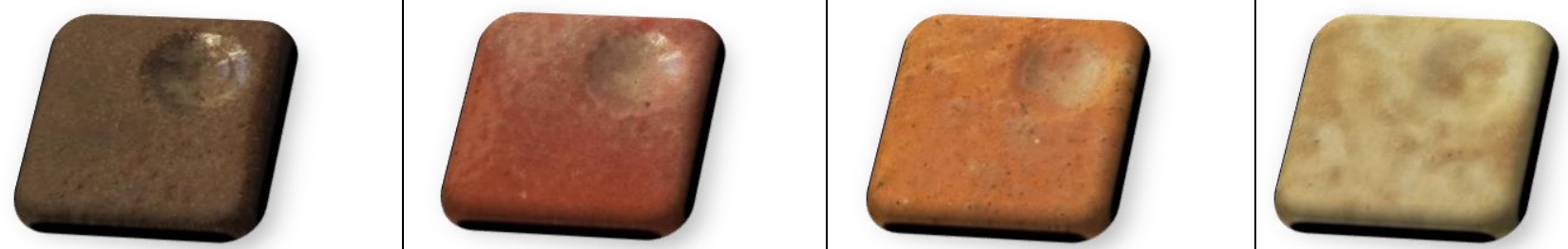

\%60 gül posası külü ve \% 40 üleksit kullanılan ikinci grupta stoneware çamurda yeterli miktarda parlak, koyu kahverengi sır yüzeyi oluşurken, kırmızı çamurda bölgesel olarak opaklaşmalar meydana gelmiştir. Şamotlu çamurda pütürlü, renksiz yüzeyler gözlemlenmiştir. Beyaz çamur yüzeyinde açık renk zemin üzerine kahverengi, pütürlü ve toplanmıș sır oluşmuştur.
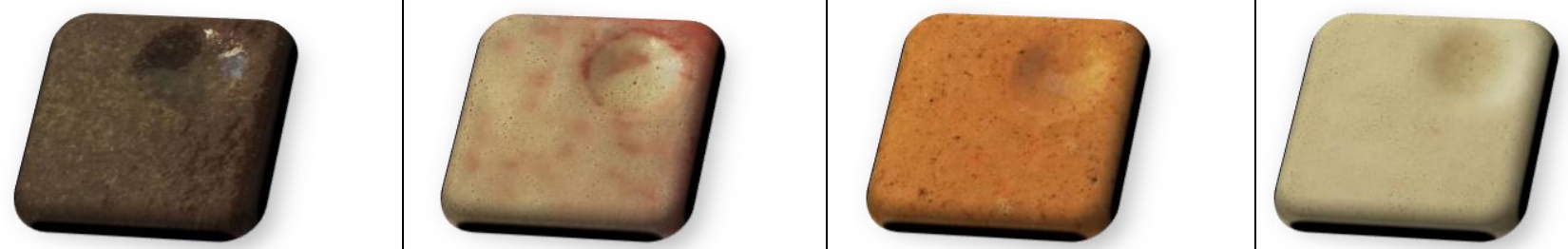

\%40 gül posası külü ve \%60 üleksit kullanılan üçüncü grupta stoneware çamurda pütürlü, koyu kahverengi bir miktar sır dokusu oluşurken, kırmızı çamurda yeterli miktarda parlaklık meydana geldiği görülmüştür. Şamotlu çamurda seyrek koyu benekler oluşurken beyaz çamurda açık kahverengi yüzey meydana gelmiştir.
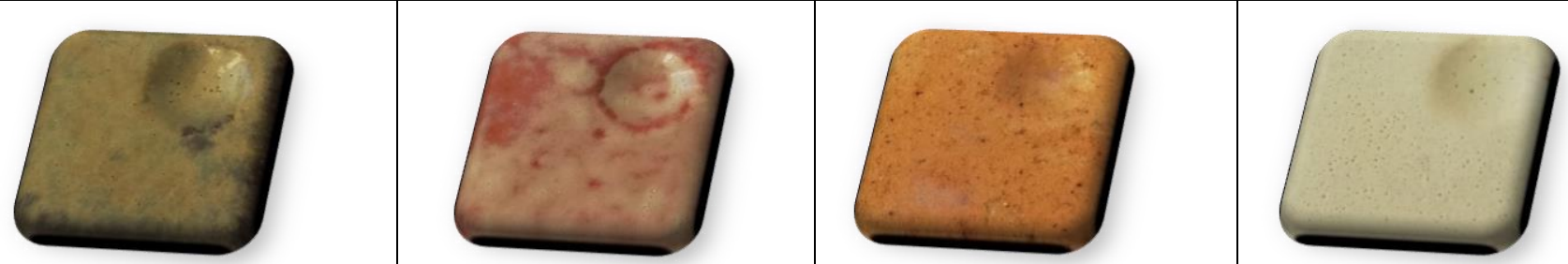

\%20 gül posası külü ve \%80 üleksit kullanılan dördüncü grupta stoneware çamurda koyu kahverengi parlak sır yüzeyi belirgin şekilde olgunlaşmıştır. Kırmızı çamur yüzeyinde opak sır dokusu oluşmuştur. Şamotlu çamur yüzeyinde parlak ve koyu benekler meydana gelirken, beyaz çamurda opak delikli görünüm oluşmuştur.

Şekil 18. Gül Posası Külü ve Üleksit İkili Harmanları

$1070^{\circ} \mathrm{C}$ 'de pişirilerek yapılan Gül posası ve üleksit kullanılarak hazırlanan harmanlarda kül miktarının \%80 oranında kullanılması ile sadece renklenme elde edilmiştir. \%60 seviyesinde kullanılan gül posası külü sonuçların sırlama dokusu oluşturabildiği göstermiştir. Ancak daha yüksek oranda sır yüzeyler elde etmek için kül miktarının \%50'nin altında kullanılması gerektiği tespit edilmiştir. 


\subsubsection{Gül Posası Külü, Sülyen ve Üleksit Üçlü Harmanları}

Seramik yüzeyi kül sırı denemelerinde ikinci olarak gül posası külü ve üleksit kullanılarak yapılan ikili harmanların denemeleri yapılmıştır.

\begin{tabular}{|c|c|c|c|}
\hline Stoneware & Kırmızı Çamur & Şamotlu Çamur & Beyaz Çamur \\
\hline & & & \\
& & & \\
\hline
\end{tabular}

\%45 gül posası külü, \%40 sülyen ve \%15 üleksit kullanılarak hazırlanan birinci grupta ki denemeler de, Stoneware çamurda parlak ve koyu kahverengi elde edilmiştir. Kırmızı çamur yüzeyinde parlak bir etkiye sahip olan sırda çatlamalar meydana gelmiştir. Şamotlu çamur üzerinde siyah benekler oluşurken, beyaz çamurda açık kahverengi tonları oluşmuş ve sır çatlamaları gözlemlenmiştir.
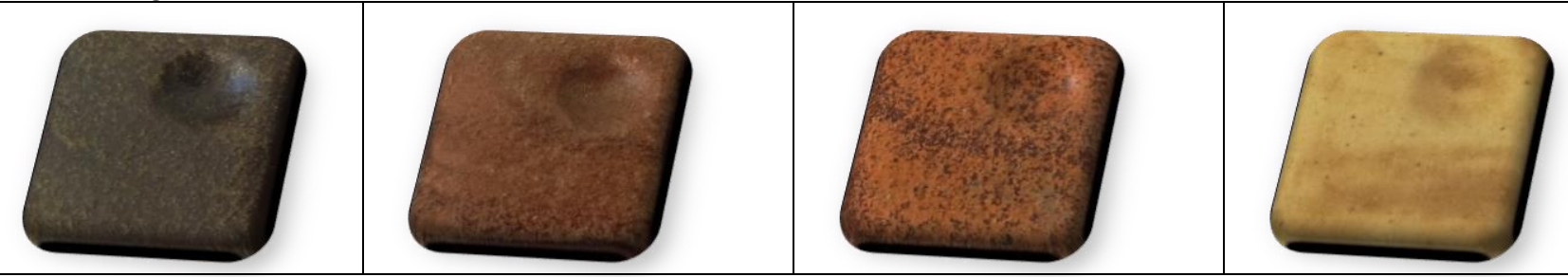

\%60 gül posası külü, \%35 sülyen, \%5 üleksit kullanılan ikinci gruptaki denemelerde, stoneware, kırmızı çamur ve şamotlu çamurda koyu kahverengi benekli sır elde edilirken, beyaz çamurda kahverengi tonlarını vermiştir. Yüzeyde az parlak bir görünüm elde edilmiştir.

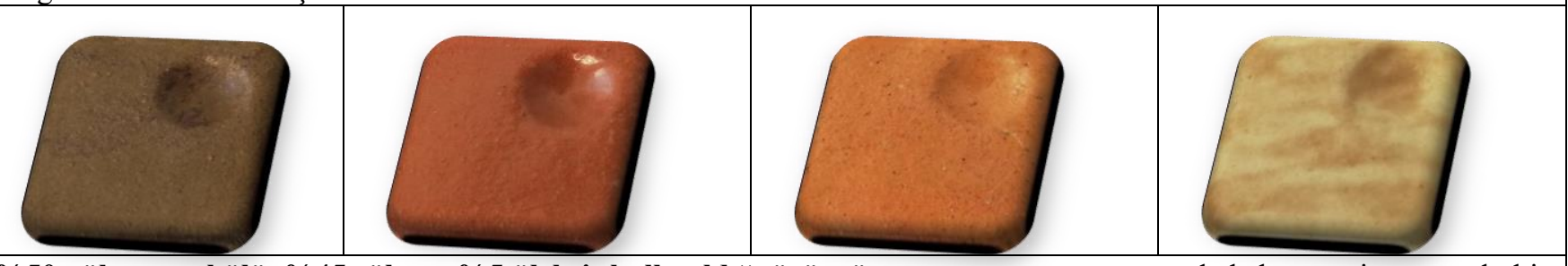

\%50 gül posası külü, \%45 sülyen, \%5 üleksit kullanıldı̆̆ı üçüncü grupta stoneware çamurda kahverengi ve pütürlü bir yüzey elde edilirken, kırmızı ve şamotlu çamurda camsı yüzey elde edilmiştir. Beyaz çamur yüzeyinde sarı kahverengi tonların ortaya çıktığı görülmüştür.
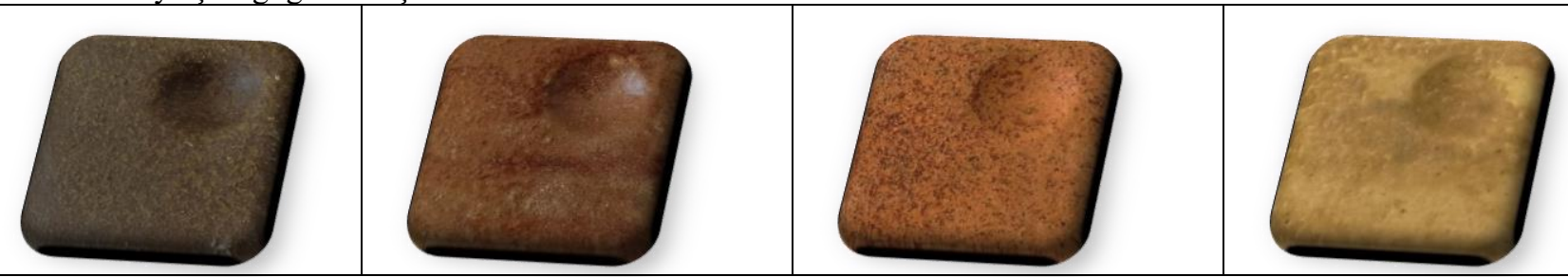

\%45 gül posası külü, \%36 sülyen, \%19 üleksit kullanılan dördüncü gruptaki deneme plakalarında stoneware çamurda mat kahverengi ve yeşil karışımı renk tonu elde edilirken, kırmızı çamurda hafif parlak bordo bir etki bırakmıştır. Şamotlu çamur üzerinde mat, benekli efektler oluşurken, beyaz çamur üzerinde toplanmalı ve mat bir görünüm elde edilmiştir.

\section{Şekil 19. Gül Posası Külü, Sülyen ve Üleksit Üçlü Harmanlar}

$1070^{\circ} \mathrm{C}$ 'de pişirilerek yapılan Gül posası, sülyen ve üleksit kullanılarak hazırlanan üçlü harmanlarda kül miktarları ile renklenme elde edilmiştir. \%60 seviyesinde kullanılan gül posası külü sonuçların sırlama dokusu oluşturabildiği göstermiştir. Ancak daha yüksek oranda sır yüzeyler elde etmek için kül miktarının \%50'nin altında kullanılması gerektiği tespit edilmiştir. 


\section{SONUÇ}

Isparta yağ gülü (Rosa damescena)'nün gül yağı imalatı sonrası oluşan organik atığı gül posasının, kül sırı olarak seramik yüzeylerde renk veren oksitler kullanılmadan ergiticiler ile yapılan ikili ve üçlü harmanlarında değişiklik gösteren sonuçlar elde edilmiştir.

Kül sırı çalışmaları kapsamında literatürde konuyla alakalı çalışmalar incelendiğinde katkı sağlayacak olumlu sonuçlara ulaşılmıştır. Organik bir atık olan gül posası, kül sırı olarak kül içerisindeki minerallerin su ile bünyeden uzaklaşabileceği düşünüldüğünden, su yerine etil alkol kullanılmış ve külün yıkanmasına gerek duyulmamıştır.

Gül posası küllerini seramik potalarda yakılarak $1050^{\circ} \mathrm{C}$ 'de kalsinasyonu gerekli olmuştur. Deneme plakalarının $1070^{\circ} \mathrm{C}^{\prime}$ de yapılan pişirimler ile olumlu sonuçlar verdiği görülmüş ve diğer hazırlanan tüm reçeteler $1070{ }^{\circ} \mathrm{C}$ pişirilerek denenmiştir.

Yapılan denemelerde renklendirici oksitler kullanılmaksızın sadece gül posası kül sırı (\%50) ve eriticinin (\%50) eşit oranlarda kullanılarak ikili harman denemelerine başlanmış. Kül sırı oranlarının artırılarak yapılan denemelerde sırasıyla elde edilen sonuçlarda eriticinin miktarı ve pişirme sıcaklığının yeterli olduğu sonucuna ulaşılmış ve benzer sonuçlar üçlü harmanlarda da denenerek görülmüştür. Eşit oranlarda (\%50 gül posası külü, \%50 eritici) kullanılarak seramik bünyelerde pişirim yapıldığında sır oluşumu gözlemlenmiştir.

Genel olarak $1070^{\circ} \mathrm{C}^{\prime}$ de yapılan denemelerde görülen matlık / parlaklık, doku ve renk geçişleri ile seramik yüzeylerin sırlanabileceği kanıtlanmıştır.

Her yıl sezonda toplanan gül çiçeklerinin damıtılması sonucu elde kalan gül yağı ülke ekonomisine büyük bir katkı sağlamaktadır. Gül posası atıklarının yararlı hale dönüştürülebileceği, seramikte artistik ve özgün kül sırları elde edilebileceği sonucuna varılmıştır.

Bu çalışmada SDÜ BAP Projeleri Komisyonu tarafindan desteklenen "ISPARTA GÜL POSASININ

SERAMIK BÜNYEDE KULLANIMI” Proje No: SYL-2019-7089 elde edilen veriler derlenmiştir. 
KAYNAKÇA

(2018). 2017 Yılı Gül Çiçeği Raporu. Gümrük ve Ticaret Bakanlığg Kooperatifçilik Genel Müdürlüğü.

Andiç, L. (1994). Artistik Amaçlı 'Kül Sırları’ Araştırma ve Uygulamaları. Dokuz Eylül Üniversitesi, Sosyal Bilimler Enstitüsü, Uygulamalı Sanatlar ASD.

Avşar, Y., Kurt, U., Tosun, İ., \& Günay, A. (2005). Isparta Yöresinden Kaynaklanan Gülyağı Atıksularının Kimyasal Olarak Arıtılabilirliği. Antalya Yöresinin İnşaat Mühendisliği Sorunları Kongresi. Antalya.

Gündeşlioğlu Demir, Ö., \& Tizgöl, K. (2016). Bir Sera Atığı Olarak Patlıcan Dalı Külünün Düşük Dereceli Seramik Sırlarında Kullanımı. Akdeniz Sanat, 9 (18).

Rogers, P. (2003). Ash glazes. University of Pennsylvania Press.

Tosun, İ., Gönüllü, M., \& Arslankaya, E. (2002). Gülyağı sanayi proses atıkları özelliklerinin belirlenmesi. 1. Ulusal Çevre Sorunları Sempozyumu (s. 864-873). Atatürk Üniversitesi, Çevre Sorunları Araştırma Merkezi Müdürlüğü.

Ünal, S., \& Akgeyik, E. (2019). IV. Uluslararası Stratejik ve Sosyal Araştırmalar Sempozyumu Tam Metin Kitabı. Burdur. 